\title{
Pneumatosis intestinalis: a rare manifestation of lupus enteritis
}

\author{
Kunal Chandwar 다, ${ }^{1}$ Rasmi Ranjan Sahoo 0 , , ${ }^{2}$ Anupam Wakhlu, ${ }^{2}$ Archana Wakhlu ${ }^{3}$
}

${ }^{1}$ Clinical Immunology and Rheumatology, King George Medical University, Lucknow, Uttar Pradesh, India ${ }^{2}$ Clinical Immunology and Rheumatology, Apollomedics Superspeciality Hospitals, Lucknow, Uttar Pradesh, India ${ }^{3}$ Radiodiagnosis, Apollomedics Superspeciality Hospitals, Lucknow, Uttar Pradesh, India

Correspondence to Dr Kunal Chandwar;

kunalchandwar@gmail.com Dr Anupam Wakhlu; anupamwakhlu@gmail.com

Accepted 30 December 2021

Check for updates

(C) BMJ Publishing Group Limited 2022. No commercial re-use. See rights and permissions. Published by BMJ.

To cite: Chandwar K, Sahoo RR, Wakhlu A, et al. BMJ Case Rep

2022;15:e247779

doi:10.1136/bcr-2021-

247779

\section{DESCRIPTION}

A 30-year-old female with systemic lupus erythematosus (SLE) presented with high-grade fever, myalgia, diffuse abdominal pain and recurrent vomiting. There was no history of diarrhoea or haematochezia. She was a known case of 'minor organ' SLE with mucocutaneous involvement, leucopaenia and arthritis and had been stable on low-dose steroids, non-steroidal anti-inflammatory drugs and hydroxychloroquine for last 2 years. Laboratory investigations revealed anaemia, leucopoaenia, thrombocytopaenia, proteinuria, active urinary sediments, antinuclear and anti-dsDNA antibody positivity, transaminitis and a high lactate dehydrogenase. Antiphospholipid antibody profile was negative. Urine culture grew Klebsiella and she initially responded to antibiotics. However, she subsequently deteriorated on day 5 of admission, with persistent bilious vomiting, diffuse epigastric pain with tenderness and sluggish bowel sounds, along with mild proximal muscle weakness. Ultrasonography (USG) of abdomen showed bowel wall oedema of $16 \mathrm{~mm}$ with loculated air foci (figure 1). CT scan of abdomen revealed dilated, oedematous bowel loops and circumferential collections of air adjacent to the lumen that ran parallel with the wall of the bowel-suggestive of pneumatosis intestinalis (PI) (figure 2).

A diagnosis of lupus enteritis was made and she was treated with pulse methylprednisolone for 3 days, followed by cyclophosphamide. Nutrition was maintained parenterally. Her symptoms started improving and bowel sounds normalised by day 12 . Repeat ultrasound showed significant reduction in bowel wall oedema. Oral fluids were reintroduced very gradually, followed by transition to semisolid and then solid diet. She responded to treatment and was discharged.

Lupus enteritis, though infrequent, is a serious complication of SLE. In a large case series of lupus enteritis, it was a presenting manifestation in up to $10 \%$ of patients with SLE. ${ }^{1}$ It may be associated with vasculitis in other organs and usually indicates an active disease, warranting a swift diagnosis and aggressive immunosuppression. Antiphospholipid antibodies have been associated with increased likelihood of thrombosis, leading to poorer outcomes. Abdominal pain is the most common and cardinal symptom, while nausea, vomiting and diarrhoea with/without fever can also be present. Severe gastrointestinal (GI) bleed, thrombosis and gangrene of intestines are dreaded and almost fatal complications.

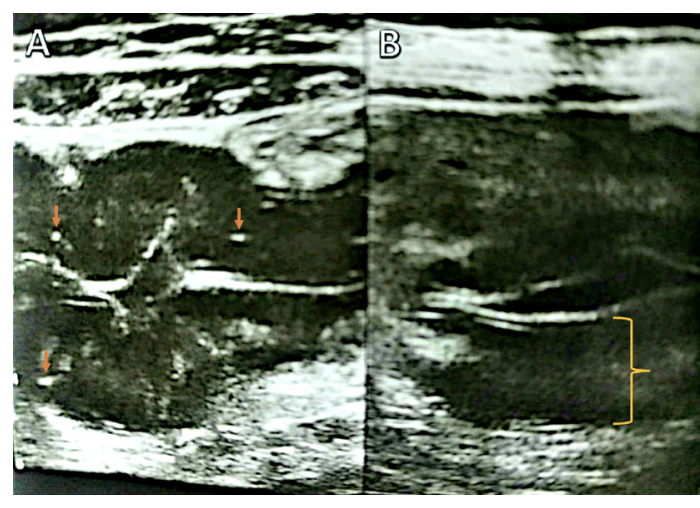

Figure 1 USG abdomen showing circumferential hypoechoic thickening (bracket) of bowel wall (B) displaying brightly echogenic foci within suggestive of air loculi pneumatosis (arrows) (A). USG, ultrasonography.

Though CT scan is the investigation of choice, bowel wall oedema on abdominal ultrasound is quite indicative of lupus enteritis. Imaging findings include intestinal wall thickening, dilated bowel loops, abnormal enhancement of the bowel wall(target sign), occlusion in the mesenteric circulation/mesenteric abnormalities (including the comb's sign) and ascites on contrast-enhanced CT (figure 1). ${ }^{2}$

PI, though not uncommon in clinical practice, is rarely encountered with SLE. The spectrum of presentation varies from asymptomatic(common), to bowel wall perforation, obstruction, GI haemorrhage and death. The investigation of choice is abdominal CT, though PI can infrequently be detected on erect abdominal X-rays and by

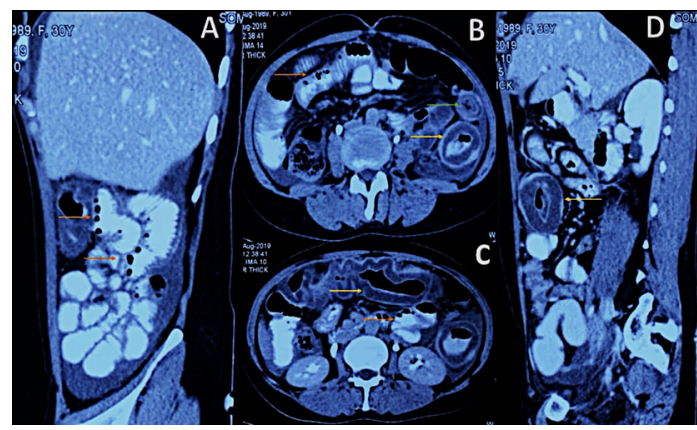

Figure 2 (A-D) Transverse and sagittal sections of contrast CT abdomen showing dilated small bowel loop displaying circumferentially thickened and oedematous bowel wall with serosal and mucosal enhancement, giving a target appearance (green arrow) (B, D-yellow arrow). Few loops display intramural air loculi suggestive of pneumatosis ( $\mathrm{A}, \mathrm{C}$ - orrange arrows). 
ultrasound. Endoscopy and endoscopic ultrasound are considered the gold standard to diagnose PI. ${ }^{3}$

Lupus enteritis is steroid-responsive and hence high-dose steroids with bowel rest and parenteral nutrition can help avoiding surgery. As our patient had active nephritis, cyclophosphamide according the modified National Institute of Health (NIH) protocol was given.

\section{Learning points}

- Lupus enteritis should be suspected in all patients with lupus presenting with abdominal pain.

- Lupus enteritis is usually a harbinger of active lupus, look for vasculitis and other systems involvement.

- Pneumatosis intestinalis is an uncommon manifestation of lupus enteritis.

- Ultrasonography is point of care and can help in early diagnosis.

Twitter Kunal Chandwar @kunalchandwar and Rasmi Ranjan Sahoo @RasmiKGMU

Contributors KC wrote the manuscript and AW and RRS were involved with the editing of the manuscript. AW was the radiologist involved in the treatment of this patient, the CT and USG reporting. KC, RRS and AW were involved in the diagnosis and management of this patient.

Funding The authors have not declared a specific grant for this research from any funding agency in the public, commercial or not-for-profit sectors.

Competing interests None declared.

Patient consent for publication Consent obtained directly from patient(s)

Provenance and peer review Not commissioned; externally peer reviewed.

Case reports provide a valuable learning resource for the scientific community and can indicate areas of interest for future research. They should not be used in isolation to guide treatment choices or public health policy.

\section{ORCID iDs}

Kunal Chandwar http://orcid.org/0000-0002-0499-0641

Rasmi Ranjan Sahoo http://orcid.org/0000-0001-6616-4989

\section{REFERENCES}

1 Tian X-P, Zhang X. Gastrointestinal involvement in systemic lupus erythematosus: insight into pathogenesis, diagnosis and treatment. WJG 2010;16:2971-7.

2 Janssens P, Arnaud L, Galicier L, et al. Lupus enteritis: from clinical findings to therapeutic management. Orphanet J Rare Dis 2013;8:67.

3 Ling F, Guo D, Zhu L. Pneumatosis cystoides intestinalis: a case report and literature review. BMC Gastroenterol 2019;19:176.

Copyright 2021 BMJ Publishing Group. All rights reserved. For permission to reuse any of this content visit

https://www.bmj.com/company/products-services/rights-and-licensing/permissions/

BMJ Case Report Fellows may re-use this article for personal use and teaching without any further permission.

Become a Fellow of BMJ Case Reports today and you can:

- Submit as many cases as you like

- Enjoy fast sympathetic peer review and rapid publication of accepted articles

- Access all the published articles

- Re-use any of the published material for personal use and teaching without further permission

Customer Service

If you have any further queries about your subscription, please contact our customer services team on +44 (0) 2071111105 or via email at support@bmj.com.

Visit casereports.bmj.com for more articles like this and to become a Fellow 